\title{
MENINGKATKAN HASIL PEMBELAJARAN ILMU PENGETAHUAN SOSIAL MELALUI PEMBELAJARAN KOOPERATIF TIPE TGT (TEAMS GAMES TURNAMENT ) PENELITIAN TINDAKAN KELAS PADA SISWA KELAS VIII/D MTs NEGERI SELATBARU TAHUN PELAJARAN 2015/2016.
}

\author{
NURLINA \\ MadrasahTsanawiyah Negeri 2 Bengkalis \\ afifahumi494@gmail.com
}

\begin{abstract}
ABSTRAK
Dalam pembelajaran Ilmu Pengetahuan Sosial di Madrasah Tasanwiyah Negeri Selatbaru ,masih banyak siswa yang kurang aktif dalam proses pembelajaran dan masih banyak siswa yang memiliki nilai di babawah KKM oleh karena itu perlu suatu upaya untuk meningkatkan hasilbelajar siswa tersebut,yaitu melalui implementasi pembelajaran kooperatif tipe TGT (teams games Turnament). Penelitian tindakan kelas ini bertujuan untuk meningkatkan aktivitas belajar siswa dan meningkatkan hasil belajar siswa kelas VIII/d MTs.Negeri SelatbaruTahun pelajaran 2015/2016 melalui pembelajaran kooperatif tipe TGT (Teams Games Turnament). Subjek penelitian adalah siswa kelas VIII /D MTs.Negeri Selatbaru dengan jumlah 17 siswa,seorang guru IPS dan seorang guru pengamat/Observer.Data yang di kumpul kan meliputi hasil belajar siswa,hasil observer guru,hasil observasi siswa. Penelitian ini merupakan penelitian tindakankelas (PTK ) yang di laksankan dalam dua siklus ,tiap siklus memiliki 4 tahapan yaitu perencanaan,pelaksanaan tindakan, pengamatan (observer) dan refleksi. Pada penelitian ini di katakan berhasil apabila siswa aktif dalam kegiatan belajarmengajar dan sekurang kurangnya $85 \%$ siswamendapatkan nilai diatas KKM (75). Hasil penelitian pada siklus Ini menunjukan rata rata hasil belajar siswa 77,94 \% dan ketuntasan belajar mencapai 70,58 \% .Dan pada siklus ke II rata rata hasil belajar siswa adalah $89 \%$ dan ketuntasan belajar siswa tercapai 88,23\%. Dari data tersebut diatas jelas menunjukan bahwa pada siklus I hasil belajar belum sesuai harapan yang berarti indicator keberhasilan belum tercapai ,sedangkan pada siklus II hasil belajar sudah sesuai yang diharapkan ,berarti indicator keberhasilan sudah tercapai.
\end{abstract}

Kata Kunci : Pembelajaran kooperatif TGT, Hasil Belajar IPS.

\section{PENDAHULUAN}

Kemajuan teknologi komunikasi dan informasi yang berkembang begitu pesat pada era globalisasi, membawa perubahan yang sangat radikal, perubahan itu berdampak pada semua aspek kehidupan termasuk pada sistem pendidikan dan pembelajaran dengan kemajuan dan perubahan yang terjadi tugas dan peran seorang guru semakin berat dan komplek bagi seorang guru mengajar bukan sekedar menyampaikan pengetahuan kepada siswa namun harus mengetahui dan mengenal sasaranya, guru harus memiliki strategi yang tepat untuk sasaran pelajaran. 
Untuk menciptakan pembelajaran yang menyenangkan, pendidik perlu merancang pembelajaran yang sesuai dengan karakteristik siswa sebagai pembelajar. Bobbi de Poerter dalam Suyatno (2009:8) mengatakan bawalah dunia mereka kedunia kita dan hantarkan dunia kita kedunia mereka. Artinya guru harus mampu menyesuaikan diri terhadap warna dan sikap siswa kedunia yang dikehendaki berdasarkan tujuan pembelajaran. Suyatno (2009:11) mengatakan proses belajar adalah proses aktif yang dilakukan oleh siswa. Hal ini berarti dalam proses pembelajaran siswa dituntut untuk aktif. Namun kondisi yang ditemui dilapangan pada siswa kelas VIII / d MTs Negeri selatbaru masih jauh dari yang diharapkan. Berdasarkan hasil pengamatan penulis sebagai guru IPS di kelas VIII/d terungkap bahwa rendahnya aktivitas siswa dalam proses pembelajaran terlihat dari siswa harus disuruh guru terlebih dahulu untuk membuka buku paket maupun buku tulis tanpa ada kesadaran sendiri, sedikit sekali siswa yang bertanya dan menjawab pertanyaan ini dikarenakan rendahnya minat baca siswa sehingga siswa tidak tahu apa yang ingin ditanyakan dan tidak dapat menjawab karena tidak menguasai materi pelajaran Permasalahan lain yang ditemui dilapangan rendahnya hasil belajar siswa terlihat masih banyak siswa yang memperoleh nilai dibawah KKM yaitu 75.

Penulis sebagai seorang guru telah berusaha memotivasi siswa agar aktif dalam proses pembelajaran IPS dengan cara memberikan kesempatan kepada siswa untuk bertanya dan menjawab pertanyaan. Sehubungan dengan kondisi di atas penulis ingin meningkatkan aktifitas belajar siswa dan hasil belajar siswa dengan penerapan Pembelajaran Kooperatif Tipe TGT (Teams Games Tournament ) dalam pembelajaran. Suyatno (2009:101) mengatakan bermain merupakan hal yang paling disukai siswa. Pembelajaran yang dilakukan melalui permainan akan membantu siswa mengurangi stress dan mengembangkan rasa humornya. Pembelajaran yang dilakukan dengan permainan berarti bahwa dalam pembelajaran melakukan kegiatan yang beranekaragam dan memasukkan permainan dalan proses pembelajaran sehingga pembelajaran dilakukan dengan suasana yang menyenangkan. Kegiatan yang beranekaragam yang dapat mengaktifkan kecerdasan yang dimiliki siswa. Oleh karena itu untuk memenuhi keinginan siswa dalam proses pembelajaran guru perlu merancang pembelajaran dengan kegiatan yang bervariasi. Pembelajaran bukan seperti yang diinginkan guru tetapi lebih kepada apa yang diinginkan siswa. Sebagaimana Campbell (2004:4) mengatakan jika siswa memiliki peluang untuk belajar melalui kelebihannya maka akan muncul perubahan-perubahan kognitif, emosional, sosial bahkan perubahan fisik yang positif dan menakjubkan.Model pembelajaran kooperatif merupakan suatu model pembelajaran yang mengutamakan adanya kelompok-kelompok. Setiap siswa yang ada dalam kelompok mempunyai tingkat kemampuan yang berbeda - beda (tinggi, sedang, rendah). Model pembelajaran kooperati mengutamakan kerjasama dalam menyelesaikan permasalaha untuk menerapkan pengetahuan dan keterampilan dalam rangka mencapai tujuan pembelajaran.

Holubec dalam Nurhadi (2008) mengemukakan belajar kooperatif merupakan pendekatan pembelajaran melalui kelompok kecil siswa untuk bekerjasama dalam memaksimalkan kondisi belajar dalam mencapai tujuan belajar. Pembelajaran kooperatif adalah pembelajaran yang secara sadar dan sistematis mengembangkan interaksi yang saling asah, silih asih, dan sili hasuh. Sementara itu, Bruner dalam 
Siberman menjelaskan bahwa belajar secara bersama merupakan kebutuhan manusia yang mendasar untuk merespons manusia lain dalam mencapai suatu tujuan. Semua model pembelajaran ditandai dengan adanya struktur tugas, struktur tujuan, dan strukturpenghargaan. Strukturtugas, strukturtujuan, dan struktur penghargaan pada model pembelajaran kooperatif berbeda dengan struktur tugas, struktur tujuan, dan struktur penghargaan pada model pembelajaran yang lain. Dalam proses pembelajaran dengan model pembelajaran kooperatif, siswa didorong untuk bekerjasama pada suatu tugas bersama dan mereka harus mengkoordinasikan usahanya untuk menyelesaikan tugas yang diberikan guru. Tujuan model pembelajaran kooperatif adalah hasil belajar akademik siswa meningkat dan siswa dapat menerima berbagai keragaman dari temannya, serta berkembangnya keterampilan sosial.

Pada pembelajaran kooperatif tipe Team Games Tournament (TGT), peserta didik di kelompokkan dalam kelompok - kelompok kecil beranggotakan empat peserta didik yang masing-masing anggotanya melakukan turnamen pada kelompoknya masing - masing. Pemenang turnamen adalah peserta didik yang paling banyak menjawab soal dengan benar dalam waktu yang paling cepat. TGT adalah salah satu pembelajaran kooperatif yang menempatkan siswa dalam Kelompok - kelompok belajar, yang beranggotakan 5 sampai 6 orang siswa yang memiliki kemampuan, jenis kelamin suku, ras yang berbeda. Menurut Slavin (2000) pembelajaran kooperatif tipe TGT terdiri dari 5 langkah tahapan yaitu : tahap penyajian kelas (class precentation), belajar dalam kelompok (teams), permainan (games), pertandingan (tournament), dan penghargaan kelompok (team recognition). Berdasarkan apa yang di ungkapkan oleh Slavin, maka model pembelajaran kooperatif tipe TGT memiliki ciri-ciri sebagai berikut :a) Siswa bekerja dalam kelompok- kelompok kecil; b) Games Tournament; c) Penghargaan dalam kelompok.

\section{METODE PENELITIAN}

Penelitian ini merupakan penelitian tindakan kelas (PTK). Penelitian ini di laksankan di MTs. Negeri Selatbaru Jalan Beringin Tahun pelajaran 2015/2016 mulai Bulan Agustus - Bulan Oktober Tahun 2015. Subjek penelitian adalah siswa kelas VIII/d MTs. Negeri Selatbaru TP 2015/2016 sebanyak 17 orang siswa, satu orang guru IPS dan satu orang guru IPS lain sebagai pengamat. Pengambilan data dilakukan penulis melaui tes dan non tes. Teknik tes meliputi ulangan harian pada siklus I dan siklu II, sedangkan teknik non tes melaui observasi aktivitas siswa melaui pembelajaran guru. Sebagai tolak ukur penelitian ini apabila nilai hasil ulangan siswa mencapai atau lebih dari nilai KKM. Indikator keberhasilan dalam penelitian ini adalah apabila sekurang kurangnya 85\% siswa memperoleh nilai minimal 75 dengan rentang 0-100, dan meningkatnya aktivitas siswa dalam pembelajaran yaitu apabila skor aktivitas sisw minimal mencapai $70 \%$. 


\section{HASIL DAN PEMBAHASAN}

\section{Hasil ulangan harian siklus I dan Siklus II}

Penerapan metode TGT ( Teams Games Turnament ) dalam pembelajaran IPS dilaksnakan sebanyak lima kali pertemuan. Tiga kali pertemuan pada siklus satu dan dua kali pertemuan pada siklus dua. Pada siklus satu mempelajari tentang Hubungan kelangkaan dengan kebutuhan manusia dan pada siklus ke dua mempelajari tentang bentuk-bentuk pasar dalam kegiatan ekonomi masyrakat. Setelah selesai membahas satu pokok bahasan guru melakukan ulangan harian untuk melihat hasil belajar siswa.

Pada kondisi awal hasil belajar siswa yang rendah, minat dan motivasi siswa dalam mengikuti pembelajarn IPS masih kurang, siswa masih belum berani mengajukan pertanyaan, menjawab pertanyaan,minat baca yang rendahdan tidak aktif dalam diskusi kelompok. Hal ini dijadikan tolak ukur untuk meningkatkan minat dan motivasi siswa hingga didapatkan proses dan hasil pembelajaran yang lebih baik. Berikut tabel hasil ulangan harian pada siklus I.

Tabel 1. Rata- rata hasil belajar IPS siklus I dan jumlah siswa tuntas dan tidak tuntas

\begin{tabular}{|l|c|c|c|}
\hline No & $\begin{array}{c}\text { Rata-rata hasil belajar } \\
\text { Siklus I }\end{array}$ & $\begin{array}{c}\text { Jumlahsiswa } \\
\text { Tuntas }\end{array}$ & $\begin{array}{c}\text { Jumlah siswa } \\
\text { tidak tuntas Siklus I }\end{array}$ \\
\hline 1 & $\mathbf{7 7 , 9 4 \%}$ & $\mathbf{1 2}(\mathbf{7 0 , 5 8} \%)$ & $\mathbf{5 ( 2 9 , 4 \% )}$ \\
\hline
\end{tabular}

Dari tabel diatas dapat di jelaskan bahwa dengan menerapkan pembelajaran kooperatif model TGT di peroleh rata-rata prestasi belajar siswa adalah 77,94 \% dan ketuntasan belajar mencapai 70,58 \% atau 12 orang siswa yang tuntas dari 17 orang siswa kelas $8 \mathrm{~d}$. Hal itu menunjukan bahwa yang memperoleh nilai besar atau sama dengan 75 hanya mencapai 77,94 \%, lebih kecil dari persentase ketuntasan yang di kehendaki yakn sebesar $85 \%$. Hal ini di sebabkan siswa masih baru dan asing terhadap metode baru yang di terapkan dalam proses belajar mengajar.

\section{Refleksi}

Dalam pelaksanaan kegiatan pembelajaran di perolehi informasi dari hasil pengamatan: a. Guru masih kurang baik dalam penyampaian tujuan pembelajaran; b. Guru masih kurang baik dalam pengelolaan waktu; c.Masih sulitnya mencari kelompok berdasarkan tingkat kecerdasan yang hiterogen.

\section{Evaluasi}

Pelaksanaan kegiatan belajar mengajar pada siklus I masih terdapat kekurangan sehingga perlu adanya refisi untuk di lakukan pada siklus berikutnya.

1. Guru harus lebih trampil dalam memotivasi siswa dan lebih jelas dalam menyampaikan tujuan pembelajaran. 
2. Guru perlu mendistribusikan waktu secara baik dengan menambahkan informasi yang dirasa perlu dan membuat catatan.

3. Guru harus lebih trampil dalam memotivasi siswa sehingga siswa bias lebih antusias dalam kegiatan belajar mengajar

\section{Hasil penelitian siklus II}

Tabel 1. Rata- rata hasil belajar IPS siklus II dan jumlah siswa tuntas dan tidak tuntas

\begin{tabular}{|c|c|c|c|}
\hline No & $\begin{array}{c}\text { Rata-rata hasil belajar } \\
\text { Siklus II }\end{array}$ & $\begin{array}{c}\text { Jumlahsiswa } \\
\text { Tuntas(\%) }\end{array}$ & $\begin{array}{c}\text { Jumlah siswa } \\
\text { tidak tuntas } \\
\text { Siklus II }(\%)\end{array}$ \\
\hline & $\mathbf{8 9 , 1 1 \%}$ & $\mathbf{1 5}(\mathbf{8 8 , 2 3} \%)$ & $\mathbf{2 ( 1 1 , 7 6 \% )}$ \\
\hline
\end{tabular}

Dari tabel 1 di atas rata-rata prestasi belajar siswa adalah $89 \%$ dan dari 17 orang siswa yang telah tuntas 15 siswa dan 2 orang siswa yang belum mencapai ketuntasan belajar, maka secara kasikal ketuntasan yang telah tercapai 88,23\% (sudah termasuk katagori tuntas ).Hasil pada siklus II mengalami peningkatan lebih baik dari siklus I. Adanya peningkatan hasil belajar pada siklus II dipengaruhi oleh adanya peningkatan kemampuan siswa dalam mempelajari materi pelajaran yang telah di sajikan dan adanya tanggung jawab kelompok dari siswa mampu untuk mengajari temanya dalam satu kelompok yang kurang mampu.

\section{Refleksi}

Pada tahap ini di kaji apa yang telah terlaksana dengan baik maupun yang masih kurang baik dengan penerapan pembelajaran kooperatif model TGT (teams Games turnament ) dari data-data yang diperoleh dapat diuraikan sebagi berikut :

1. Selama proses belajar mengajar guru telah melaksanakan semua pembelajaran dengan baik.meskipun ada beberapa aspek yang belum sempurna ,tetapi presentase pelaksanaan masing-masing cukup besar.

2. Berdasarkan data hasil pengamatan diketahui siswa aktif selama proses belajar mengajar: a)Kekurangan pada siklus I sudah mengalami perbaikan dan peningkatan sehingga lebih baik; b) Hasil belajar siswa pada siklus Ii secara klasikal sudah mencapai ketuntasan.

\section{Evaluasi}

Pada siklus II guru telah menerapkan pembelajaran kooperatif model TGT dengan baik dan dilihat dari aktifitas siswa serta hasil belajar siswa pelaksanaan proses belajar mengajar sudah berjala dengan baik, maka tidak diperlukan revisi terlalu banyak,namun yang perlu di perhatikan untuk tindakan selanjutnya adalah memaksimalkan atau mempertahankan apa yang telah ada dengan tujuan agar dalam pelaksanan proses belajar mengajar selanjutnya penerapan pembelajarn kooperatif model TGT dapat meningkatkan hasil dari proses belajar mengjar dan tujuan pembelajaran. 


\section{Ketuntasan Belajar}

Melalui hasil penelitian ini menunjukan bahwa pembelajaran kooperatif model TGT (Teams Games Tournament ) memiliki dampak positif dalam meningkatkan prestasi belajar siswa. Hal ini dapat di lihat semakin mantapnya pemahaman dan pengusaan siswa terhadap materi yang telah di sampaikan guru selam proses belajar mengajar (ketuntasan belajar meningkat dari siklus I ke siklus II yaitu dari 70,58 \% menjadi 88,23 \%. Ini berarti ketuntasan belajar klasisikal sudah tercapai

\section{Kemampauan Guru dalam mengelola pembelajaran.}

Berdasarkan dari anlisis data, diperoleh aktivitas siswa dalam proses pembelajaran kooperatif, dalam setiap siklus mengalami peningkatan .hal itu berdampak positif terhadap peningkatan prestasi belajar siswa dan penguasaan materi pelajaran yang telah diterima selama ini, yaitu dapat ditunjukan dengan meningkatkanya nilai rata-rata siswa pada setiap siklus.

\section{Aktivitas guru dan siswa dalam pembelajaran}

Berdasarkan pengamatan, aktivitas siswa dalam proses belajar mengajar dengan model Pembelajaran teams games tournament (TGT) dimulai dengan penyampaian materi, belajar dalam kelompok, dan games turnament memperlihatkan keaktifan dan kerjasama siswa yang baik baik untuk siswa yang mampu maupun siswa yang kurang mampu. Dalam hal ini menunjukan bahwa model pembelajaran kooperatif sangat diperlukan agar kecerdasan siswa baik intelegensi maupun emaosi bisa tersalurkan dengan baik agar nantinya siswa siap bermasyrakat. Sedangkan aktivitas guru selama pembelajarn IPS telah melaksnakan langkah-lang kah pembelajarn kooperatif model TGT dengan baik .hal ini terlihat dari aktivitas guru yang muncul diantranya aktivitas membimbing dan mengamati siswa dalam mengerjakan kegiatan,menjelaskan materi yang kurang di megerti siswa memberikan penghargaan kelompok terbaik dan motivasi bagi kelompok lainya.dimana persentase untuk aktifitas diatas cukup besar.

\section{KESIMPULAN}

Simpulan Penelitian ini yaitu: (1) Pembelajaran kooperatif model TGT (teams games turnament ) meningkatkan hasil belajar siswa yang di tandai dengan peningkatan ketuntasan belajar siswa dari siklus I ke siklus II yakni dari 70,58 \% menjadi 88,23 \%; (20 Penerapan pembelajarn kooperatif model TGT berpengaruh positif ,yaitu dapat meningkatkan motivasi belajar siswa dalam belajar IPS ,hal ini di tunjukan dengan antusias siswa dalam mengeluarkan pendapat ,bertanya dan menjawab pertanyaan; (3) Pembelajaran kooperatif model TGT memiliki dampak positif terhadap kerjasama antar siswa,hal ini di tunjukan dengan adanya tanggung jawab. Saran yang dapat disampaikan yaiti (1) Penerapan pembelajaranKooperatif model TGT (teams games tournament) dapat dijadikan sebagai salah satu alternatif untuk meningkatkan hasil belajar dan aktivitas siswa; (2) Permainan perlu dirancang lebih menantang dan mengarah kepada seluruh aspek kemampuan kognitif, psikomotorik dan afektif. 


\section{DAFTAR PUSTAKA}

Baharudin dan Nurwahyuni. (2007) .Teori Belajar dan pembelajaran.J ogjakarta : Ar Ruzz Media

Suyatno. (2009)Menjajah Pembelajaran Inovatif.surabaya : Mesmedia Buana Pustaka Nurhadi. (2003) Pembelajaran Konstekstual (Contextual Teaching And

Learning/CTL,Malang : Penerbit Universitas Negeri Malang

Ali, Muhammad. (2000). Guru dalam Proses BelajarMengajar, Bandung; PT.

SinarBaruAlgesindo

Arikunto, Suharsini. (1996). Penilaian Program Pendidikan. Jakarta: PT. BumiAksara Syah, Muhibbin. (1995). Pysikologi Pendidikan. Bandung : PT RemajaRosdakarya 